\title{
From a Peasant "World" to a Collective Farm: How the Preconditions of the Catastrophe in a Peasant Environment Ripened
}

\author{
Svetlana V. Lourié* \\ Sociological Institute of the Federal Center \\ of Theoretical and Applied Sociology of the RAS \\ 25/14 7th Krasnoyarmeyskaya Str., St. Petersburg, \\ 198005, Russia
}

Received 21.01.2018, received in revised form 18.06.2018, accepted 29.06.2018

A Russian peasant worldview was built on the basis of interaction and counteraction of two internal alternatives: "worldly" (communal) and national. A peasant community had been arising in Russia in the 13-14th centuries and had occupied a central place in all spheres of peasant life. It has become a selfgoverning autonomous "world", an economic institution and religious unity - a church parish. And the state itself was perceived by peasants as a large community. The community became the only source of legitimacy in the peasants' minds when, in the era of serfdom, it was legally deprived of any protection. It has its own image of a proper state. It fights for self-government and "black repartition" as fair land management. And then peasant riots in Russia do not cease. The shortage of land was partially mitigated by the colonial movement to the eastern regions of the Russian Empire, but the tension between the peasant community and the state was continuing. By the beginning of the 20th century the religiousness of peasants had considerably weakened, which was the reason for a certain distortion of a parish basis of the community. Therefore, the "worldly" alternative turned into an end in itself, and at the turn of the 21-20 th centuries peasants were more strongly influenced by the propaganda of provocateurs-revolutionaries who called for a violent "black repartition".

The peasant community lost its ideal meaning, when it had accepted the "black repartition" from the godless Soviet state after 1917. And the balance between "worldly" (communal) and national alternatives in the peasant worldview was violated. As a result, the community, having accepted the Soviet state as its own in the 1920's, and the state atheism as a "state religion", is not ready to resist collectivization. For the first time in centuries, peasants do not expect antagonistic acts from the state, and it is then when they receive a stab in a back.

Keywords: Russian peasant community, church parish, peasant riots, collectivization.

DOI: 10.17516/1997-1370-0293.

Research area: culturology.

There were two alternatives in the minds of the Russian peasants - worldly (communal) and state - which interacted and fought each other.
The community originated in Russia in the $13-14^{\text {th }}$ centuries and only in later times took the form, which many researchers took as

(C) Siberian Federal University. All rights reserved

* Corresponding author E-mail address: E-mail: svlourie@gmail.com 
a frozen ancient form, of a kind of land village community. Until the $17^{\text {th }}$ century peasants usually settled in farmyards, and a volost' became the community uniting so many households that there was a possibility of self-government. In any new region where Russian peasant colonization took place, the community was formed very quickly. Moreover, it often goes full circle of its development. Therefore, there were communities of different types in different regions of the state. For example, volost'-communities were widespread in Siberia in the early $20^{\text {th }}$ century: they were transformed into village-communities only with the growth of population in connection with the process of transformation of a capture form of land use into an equal one in the event of shortage of land. Transformation of the community as an economic mechanism aimed at strengthening of the principle of equalization, for example, a transition occurred from homestead equalization to the per capita equalization or "by the need". The worldview of peasants was based on a notion that land, like God's property, should be used in the manner of God, therefore in the case of abundance of land this meant that everyone could take as much he could process, and in case of shortage of land, it was fairly redistributed. Even after the legal extension of the right to private ownership of land and peasants, although they bought land, but they did not believe that the land really became their property believing that the land they bought would go into general redistribution. It happened very often: the community bought land from a peasant and included it in its common land fund.

Unlike the communities of many other peoples, the role of the Russian peasant community up until the $20^{\text {th }}$ century increased. If in Russia the reallocation of land began in connection with the growth of the land deficit, in Germany, on the contrary, individual ownership of land developed under the influence of population growth, and as soon as the population decreased, a return to joint use of land occurred. And by the $20^{\text {th }}$ century the peoples of the Near and Middle East - Arabs, Persians, Turks, Kurds - had a transition to individual ownership of the land, and there was no reallocation at all.

The community can be regarded as the main type of Russian sociality. The word "community" is synonymous with the word "world", and the concept of "world" was central to the consciousness of Russian peasants. A peasant recognized himself as a member of the Russian society, but not as an individual, but as a member of a certain community, a certain "world". A "world" is an autonomous selfsufficient integrity. "From a legal point of view, it was an administrative unit together with a church canonical unit - a parish; from a point of view of property law, the "world" was a land community since it disposed of land" (Iushkov, 1913: 10). Ideally, the "world" also had certain attributes of statehood: a court of "common law", punitive functions (up to expulsion by the community assembly conviction). People asked the "world" for intercession and filed petitions with it. The "world" collected taxes and paid them to the state authorities. In all external contacts, including with the state, it acted as a single whole and defended each of its members. It reached the point that even at the beginning of the $19^{\text {th }}$ century, during the Patriotic War of 1812, the "world" took over defensive functions: village self-defence groups were organized. They only protected the land that was used by their community from the enemy.

A structure of the Russian society back in the $15^{\text {th }}$ century, and in the North up until the $17^{\text {th }}$ century, had represented a federation of "worlds" with complete autonomy for each particular "world". The "world" was not a structure inherent only in the peasantry then. It included members of various classes. A city, a street, and an urban "end" (a district of the city) 
all were the "world". The "worlds" of each region were united in a zemstvo (county council), and zemstvo was already a part of the Moscow state. For a very long time this model was perceived as standard, regardless of how it was embodied in practice. The state itself, from this point of view, was understood as a system that unites numerous "worlds" meaning it was "the world" in a broader sense (Bogoslovskii, 1903: 192). "The Russian people" was also understood as the "world" in a broader scope. Thus "there is the world of the whole earth, the Russian land over the local worlds, on the one hand, and the world in a sense of the people, on the other." (Ostrovskaia, 1912: 5).

This is where the contradictions in Russian consciousness begin. The real state of Russia has never been such a "world". And if at some initial stage its external manifestations were such that the Russian people could imagine it to be a larger "world" through certain correction of perception, then with the growth of centralization and with the establishment of serfdom the position of the peasant community in the Russian state became more and more ambiguous, and it often turned into direct confrontation with the state. Even by the end of the $19^{\text {th }}$ century, when the former functions of the "world" seemed to have begun to return to the community, when its autonomy was again recognized, its legal norms (customary law) were studied and introduced into official judicial practice - all these innovations did not cause trust among the peasants. People continued to feel themselves in a deaf confrontation with the state, stubbornly failing to comply with the rulings of the authorities that they disliked, avoiding any meetings with representatives of the state whenever possible, and always ready to move on to open confrontation.

Nevertheless, peasants' perception of themselves as members of a large statecommunity was also evident at the beginning of the $20^{\text {th }}$ century and determined, for example, the psychology of the mass peasant movement when any official paper relating to resettlement issues was perceived by the people as a royal cry for resettlement, and the motif of colonization as public service was sufficiently clearly seen in the nature of the popular rumour and rumours about colonization of the outskirts of the Russian Empire (Kaufman, 1905: 190).

The people everywhere believed in the "black repartition" - the all-Russian equalization, the fair redistribution of the Russian land among all members of the Russian society on the same principles as the equality within the individual communities. It is known that peasants refused to buy land from the landlords on very favourable terms, or, on the contrary, they agreed to unprofitable ones, due to the fact that a common repartition was about to take place anyway (Efimenko, 1884: 142).

It is important to remember that the "world" was also a parish. The worldly gathering, in fact, was also an organ of the religious community. The affairs of the land community and the parish did not differ in any way. Before the $18^{\text {th }}$ century the community chose the clergy, that is, the priests and clergymen (Iushkov, 1913: 3). The church treasury acted as a credit institution that gave loans to members of the community (Sokolov, 1895: 25). There was a view that "parochial autonomy is part of the self-government of zemstvo... The separation of the religious community from the world could only happen under the influence of the church and state power" (Iushkov, 1913: 110). The parishes consisted of constant interaction with monasteries - centres of educational activity.

Up to a certain time the state did not attempt to violate the foundations of peasant self-government, although it sought to limit the mobility of peasants. The peasants acquired personal dependence on a landowner only with the introduction of the Petrine censuses, when any 
connection between a peasant and the state could happen only through the landlord. Throughout the $18^{\text {th }}$ century, the position of a peasant became increasingly close to that of a slave, and finally, "a decree on the sale of people without land was issued to meet state and private debts from public auctions, but without the use of a hammer" (Kizevetter, 1923: 55).

The community was deprived of the slightest legal protection. In addition, if the actions of the authorities at first could be explained with a certain amount of exaggeration by the desire for the unification of state life, then during the period of Catherine II this weak justification for the existing regime did not work out: serf dependence of a peasant ceased to be conditioned by the obligatory service of his owner to the state. During the whole $18^{\text {th }}$ century, explosions of riots of serfs followed each new measure aimed at the expansion of noble privileges.

Since that time, the riots in Russia have not subsided. The peasants kept their own image of the state within themselves and sort of regarded themselves as the state. At this, the king was the exteriorization of his own image. As Lev Tikhomirov wrote, "the monarchy survived only thanks to the people, who continued to consider legitimate not what Peter ordered, but what was in the minds and conscience of the monarchical consciousness of the people" (Tikhomirov, 1923: 112). In times of peasant wars, the insurgent peasants parodied the state. In the period of the Pugachev rebellion, the "generals" and "officials" - the "state hierarchy" appointed by him were crowded around the self-proclaimed emperor. Thus, during the first Russian revolution, peasants believed that provocateur students would have to take the place of the "abolished superiors". And some young peasants "called themselves students", that is, the peasant community put forward a new bureaucracy from its environment (Kretov, 1925: 59). As a gendarme officer from the Penza province remarked, "the word "world" acquires a great significance for peasants". They refer to it as a legitimate support even in their unlawful actions". The people have unshakable conviction that "the tsar decides as the peasants say at gatherings" (The peasant movement..., 1926: 11, 115). This feeling was constantly actualized in the period of serfdom. Therefore, during this period, the community consciousness is exacerbated, the community, in essence, turns out the only power for the peasant - their own peasant community and Russia-community existing only in their minds. Any peasant revolt is a riot for the community and for the Russian community, for the people's state.

"The Tsar and the people" is the central problem of any peasant revolt. On the other hand, the central problem of peasant revolt can be presented as opposition between the "world" and the state power. Russian rebellion has always been an expression of a conflict between two internal alternatives of the Russian people: "worldly" and "state". The intense image of the defending tsar was formed in the minds of the people precisely in response to the constant conflict between the people and the state. The tsar was seen to the people as their ally in the camp of strangers, the popular rumor even attributed the occupation of grain husbandry to him. And then the entire state administration turned out to be "the fifth wheel in the cart", "the infidels and crafty royal servants" who hinder the direct connection of the tsar and the people. One can imagine the extent to which the Russian peasants' perception of reality caused by psychological defines was distorted: if many peasant goers to the tsar wrote to their fellow villagers about the successful resolution of their affairs, it cannot be assumed that the peasants constantly chose pathologic liars as their emissaries. When the peasants who refused to obey to a landowner "could personally hand in a petition to the tsar with their requests and 
an explanation of the motives for their actions, and the tsar accepted this petition from the hands of the peasants", they never doubted a positive resolution of their problem and refused to believe the negative decision considering it to be forged (Rakhmatullin, 1990: 16). At the same time, however, the peasants were not always satisfied with the current ruling tsar. Thus, the hope was often put not on the real tsar, but on some mythologized image of him. One way or another, but during revolution of 1905 , the governor of the Poltava province, Prince Urusov, emphasizing the loyalty of the people to the tsar, pointed out that "this belief can be a cause to very undesirable phenomena, give rise to riots" (The peasant movement..., 1926: 105). Much later, the problem of the tsar and the people was formulated by Leon Trotsky: "If the White Russians realized to shout out the slogan of the "Kulak Tsar" - we would not even have stand two weeks" (Cited by: Solonevich, 1991: 33).

What did usually serve as an occasion for rebellion? Almost always the same thing - a rumour that "strong people" and landlords violate the will of the tsar. This will, in their understanding, was always the same - to give land to the peasants, to implement "Black Repartition”, all-Russian equalization. This rumour could occur in a variety of forms. For centuries we have met with the manifestations of the legend about a hiding tsar: or that one or another tsar has not died, but is waiting for his hour to lead the people in defence of a legitimate monarchy, or that one or another rightful candidate has been displaced by the landowners and awaits his hour too. And these images were sometimes quite fantastic. Thus, during the revolution of 1905, "the peasants in Volkovskii county of Kharkov Governorate said that the Grand Duke Mikhail was coming, distributing land and authorizing looting. The peasants even imagined special clothes for the Duke. He was shining. They attributed supernatural powers to him." (Kretov, 1925: 58). Any word coming from the authorities could be interpreted as an indication of the all-Russian equalization. And the peasants considered it their duty before the tsar to achieve the implementation of "his will", and then the cause of a riot could be any event of a local scale, such as doubts about the legality of the inheritance of any land or actions of certain officials.

The features of provocation are clearly visible in the actions of the insurgent people. The people deliberately provoke the authorities to respond, to demonstrate the power. At its peak point, these actions result in self-provocation, the brightest example of which can be the events of the Bloody Sunday, January 9, when the people decided to test by experience whether they have a tsar and whether they have God. Moreover, as evidenced by eyewitnesses, the people were ready for a negative response. During the working meetings Gapon "talked about the possibility of an attack, about the imminent danger, that they might not be received by the tsar, and the tsar could refuse to listen to his people. He ended these speeches with the words: "....and then we do not have a tsar!" "And then we do not have a tsar," the assembly unanimously echoed his words and enthusiastically was ready to follow Gapon to the end". There is an impression that the people unconsciously wished for a negative answer - a response that would untie his hands. And after the shooting of the crowd: "There is no more God! There is no longer a tsar! - Gapon wheezed tearing off his fur coat and cassock. There is no God! There is no tsar! - confirmed the surrounding people with a severe echo." (Cited by: Ninth of January, 1925: 90, 101).

According to the exact observation of the researcher of the beginning of the $20^{\text {th }}$ century, N.N. Firsov, "under the term "Razin revolt" one can understand not only a certain political and 
social struggle, but also a certain set of feelings and aspirations." Razin revolt left a "bright and beloved memory" among the people. Moreover, in popular song poetry, the people praised the father Stepan Razin high, even higher than their beloved ancient hero Ilya of Murom, although even during his lifetime Razin was considered to be a sorcerer, and this reputation remained in folk songs and legends. The people knew that Razin was a great sinner, and thought that the earth had not accepted him for his sins, and that he would come again, when sins would multiply in Russia." (Firsov, 1920: 52-53). Here, as if there is some kind of rapture on the edge of a gloomy abyss. And this feeling, as an obsession, goes through the whole of Russian history and has many incarnations. Here we can note another very significant point: the people felt that the "black repartition" would come when sins in Russia multiplied.

By the $20^{\text {th }}$ century, when a tide of unrest had already swept through some southern and south-eastern governorates, the peasants greeted the Socialist-Revolutionary propaganda with enthusiasm. What did the SocialistRevolutionaries said to the people that, despite their anti-monarchy attitude, they were accepted as "people who are trustworthy?" (Spiridovich, 1918: 173). The program of the Socialist Revolutionaries was a formulation of paradigms of the traditional consciousness of peasants that was quite accurate and clearly based on a true sense of village life. The Socialist-Revolutionary program concentrates the elements of the "worldly", a territorial alternative of the Russian consciousness. An idea of the state as a federation of autonomous self-governing lands is proclaimed, that is, Russia as a large community, a federation of autonomous "worlds" (Aveleani, 1917: 20).

Correlation of the people's consciousness with the Socialist-Revolutionary program gave a terrible effect. And by accepting this program, the community ceased to be a religious unity. Archbishop Mitrofan of Mogilev said that the community was once very convenient for teachers of the people, but "now this advantage is used by people who have oust natural teachers, they try to sow discord, instil a sense of hatred, envy and vengeance in peasants." (Cited by Lanshchikov, Slutskii, 1990: 162). The disruption of the interconnectedness of a parish and a "world" inevitably caused a state of chaos, although this chaos was brewing slowly, and for the time being, it did not seem to touch upon the foundations of communal life. Its result will affect later.

The peasant revolution of 1905 forced the authorities to think about the essence of the community for the first time, and the state begins a targeted attack on the communal system. This position is taken by most Russian statesmen. Already in 1906, Count Witte, the former supporter of the community, initiated a decree to facilitate the individual withdrawal from the community for individual householders.

The revolt seemed to have a good influence on the communal structures, kind of strengthened them. Thus, after the revolution of 1905, the community was a fairly solid integrity able to resist the direct pressure from the government during the Stolypin agrarian reform. The Rural movement, despite all the efforts of the government, practically did not take root in the central and especially northern regions of Russia, where "worldly traditions were particularly strong." (Conquest, 1988: 147). Peasants' resistance to the reform was fierce and irrational, which is especially striking because of the overactive participation of women in it. In police certificates, we can find the following comments: "A crowd of women with stakes... Teenagers followed women... A crowd of women with sticks and scythes... There was a crowd of peasants, mostly women... Women armed with pitchforks..." 
The revolution of 1917 also caused the revival of the community. "The community played an exceptionally important role in life of the rural population of that time. $<_{\ldots}>>$ The community with its "worldly" bodies of self-government perfectly united local peasants to fight against the landlords, and its remanufacturing mechanisms proved to be quite suitable for the distribution of landed estates among peasants. During the equalizing redistribution of lands, the peasant community revived and strengthened absorbing the bulk of the land... Frequent, almost annual redistributions of the land that began during the agrarian reform period did not stop even with the transition to the NEP." (Danilov, 1975: 141, 143). And by this time the community had ceased to be a parish.

It did not happen all of a sudden. It was serfdom that completely deprived the parish of any autonomy. Elections of a priest by the parish, which was formally practiced in the first half of the 18th century, in reality already "depended on the will of the owner, so that the consent of peasants could not be asked for." (Znamenskii, 1873: 19). The landlord looked at his parish priest as if he was his own servant. "The arbitrariness of landlords was so great that they could deprive a priest of bread, home, position." (Ivanov, 1905: 19). In addition, the government entrusted the parish clergy with immediate police duties. In order to combat schism and political distemper, priests were obliged to inform the government about the schism and ripening riots. Then the government approved a decree containing strict prohibition to all church and clergy servants to "write and sign peasants' complaints against the owners." (Znamenskii, 1873: 486). The parish priest was also charged with "a very delicate and painful duty: to monitor peasants' abstention with the census. The responsibility to search for "credited souls" fell precisely on the parish priests, and they were punished for the concealment of these souls: defrocking and hard labour." (Znamenskii, 1873: 14). All these measures also affected many Orthodox peasants - because the displeasure of peasants was country-wide, their own slavish position was deprived of the slightest legitimacy in the eyes of the peasants. Similarly, it was also deprived of legitimacy in the eyes of a parish priest closely connected with the peasant environment, but obliged under the fear of punishment to preach about the need for serfdom, its legitimacy and sanctification by God, which, of course, "cheapened such preaching in the eyes of the people." (Znamenskii, 1873: 55).

By all these measures, the government actually achieved a situation when the priests could turn into anyone, but not into teachers of the people. On the one hand, they, by virtue of their humiliated and distressed state, were getting closer to peasants, but on the other hand, they were deprived of moral authority among the peasants because of those duties that were imposed on them by the government. During peasant riots, they were not able to take the position that could prevent the riotous behaviour and outrage of the rebellious people. They either sided with the unlawful authorities, and in an obvious way, not out of conviction, but out of fear of their oppressors, and thus they were deprived of the influence on the peasants, or adjoined to peasant riots, became the participants and, wishing or not, gave moral approval to the riotous behaviour of the peasants.

The link between the peasantry and the monasteries was also destroying. In 1764, the government issued a decree on the establishments of the monasteries, and a large number of monks having a hesychast, truly Orthodox tradition and served as teachers to the people had to leave Russia. Throughout the entire $19^{\text {th }}$ century, religiosity in the peasant environment is becomes less popular: the analysis of confessional statements indicates that since the middle of the 
$19^{\text {th }}$ century the number of peasants who went to confessions decreased (Litvak, 1989: 206). And according to ethnographers, the moral state of the Russian peasants at the beginning of the $19^{\text {th }}$ century was much higher than at the end, and in general the whole $19^{\text {th }}$ century was much more pagan than the $17^{\text {th }}$ and $18^{\text {th }}$ centuries.

If in the past, a peasant rebellion made it possible to relieve tension, and then someone in the community reminded old meanings, and the community returned to them, then by 1917 there were not enough people who could remind them.

And now a century-old dream of peasants the "black repartition" has come true! And it was done by murder and robbery. The Bolsheviks, temporarily using the Socialist-Revolutionary program, seemingly fulfilled what they promised: they gave land to those who worked on it. In that program, the labour customs and customs of selfmanagement were accurately captured - only Orthodoxy had no place in it. In the 1920's, the years of the NEP, there is apparent flourishing of the peasant community in a Russian village, land redistributions became annual, the community worked from dawn to dusk more than ever. Everything was revived: the labour law of the peasant community, its self-government, its internal structure of relations, but the community lost its meaning - it stopped being a parish.

The churches in villages continued to exist. From the beginning of the NEP and up to collectivization, forcible closing of churches was a rare case. Anti-religious propaganda in the village is rather sluggish. Thus, "in March 1928, in Volokolamsk district there were branches of the "Bezbozhnik" (Atheist) society with 5 rural units. Classes are conducted regularly only in two groups. Due to a lack in management staff, the work is developing poorly; there is no literary material. Almost no disputes." (Stopanin, 1926: 63).

Evidence of the religious state of villages of that time is almost all the same. "A form, way of life, habit are preserved. People go to church out of habit when they have something to wear, and if they do not, then they do not go there... Instead of 600-700 people who went to church before the revolution, no it is $150-200$ people... True atheists are a rare case. They are known to every peasant: one in Tikin, two in Znamenka." (Golubykh, 1926: 117). According to a witness in 1925 , "it was very interesting for me that young people do not go to church, they organize dancing gatherings against the church; some old women curse them, and the youth from about twelve villages organize dances." And the old people themselves "sometimes take part in such actions that tease the priests and gods." (Leningradskie rabochie..., 1925: 13-14).

Having taken at face value the all-Russian equalization, the "black repartition", which initiative seemed to come from the state, the peasantry, perhaps, for the first time in centuries does not look at state power as something hostile. Two opposing alternatives - worldly and statist seemed to begin to merge. Since the state has responded to the aspirations of community has carried out the redistribution of land, then the community begins to gradually trust the government as such. Atheism begins to take root in a village precisely as a state religion. The peasantry is trying to accept what the state offers.

Attitude to the Soviet power was improving right in front of our eyes. In 1925, the observers in a village noted: "Those peasants who in 1924 cursed the Soviet authorities, to my surprise, are now grateful to them... A comrade N. from the Petrogradskii district writes: "There is a great a change in the environment of peasants and a change in opinion on the activities and situation of the country and government compared to 1922, when I personally had to work in the village.” (Leningradskie rabochie, 1925: 12). The interest in public life among people in this period is very great. "A peasant rarely sees a newspaper. 
But, as soon as he gets a newspaper, he reads it from the first word to the last... The contents of the newspaper, the smallest facts marked by it, are transmitted to each other in the evenings and on holidays. The contents of the newspaper are learned by dozens, hundreds of peasants from oral transmission. The peasants are most interested in our international situation. This topic is the most interesting to them." (Golubykh, 1926: 44). Peasants "show great interest in social and political life... A question of Anglo-Soviet relations is very vividly discussed." (Kolesnikov, 1925: 26).

The "worldly" and state alternatives are getting combined in the minds of the peasants. A state of revolt is strengthening. What happened during the collectivization in the Russian village? It seemed to be in a state of insanity. There is some random swarming. "The village gathers, the village is debating, the village is discussing. Political issues are discussed everywhere: at a mill, at a bazaar, in a local council, at school, and at endless meetings and gatherings." (Ulasevich, 1930: 18). "People went mad, they do nothing, hang around the street." (Pokrovskii, 1989: 308). Testimonies about the life of the village of that time are very, very contradictory. And, it seems, you can take any facts at face value. There was also a terror. However, this kind of evidence seems to be reliable as well: "I must say, and it amazed me that in the village they often say: "We have built socialism" and "we are bad builders of socialism", etc." (Ulasevich, 1930: 20).

One can observe regularity that resistance arose as a response to direct violence by the authorities. If there was no such direct violence with assault by the authorities, if the peasants were persuaded "in an amicable way", they surrendered on good terms. A powerful system of control over the peasantry, which the government wanted to create through the political departments of machine and tractor stations, through "groups of atheists", through sending communists to a village, was not very effective. The power of the Bolsheviks in a village was far from all-embracing. The number of Communists was small. Thus, "in the Volokolamskii district near Moscow in $75 \%$ of villages there are no party members at all." (Stopanin, 1926: 49). By the summer of 1929, in Soviet Union, there was one party unit per three village councils, and most of them were fictitious. The effectiveness of sending urban emissaries to a village is also problematic. "Twenty-five thousand" - what could they do in the boundless Russia? In addition, we can see a lot of false reporting and in all that concerns the patronage of the city over the village.

The village surrendered itself, and surrendered almost without resistance, admitted its defeat. And then complete apathy came. There were no more revolts in the village.

\section{References}

Aveleani, S. (1917). Zemskoi vopros v programme partii sotsialistov-revoliutsionerov [A territorial question in the program of the Socialist-Revolutionary Party]. Pg.: b.i., 28 p.

Bogoslovsky, M. (1903). Zemskoe samoupravlenie na russkom Severe v XVII veke [Territorial self-government in the Russian North in the 17th century]. Moscow, Synodal'naia tipografiia, $215 \mathrm{p}$.

Conquest, R. (1988). The Harvest of Sorrow, London, Overseas Publication Interchange Ltd, 290 p.

Danilov, V.P., Kim, M.P., Tropkin, M.V. (1975). Sovetskoe krest'ianstvo. Kratkii ocherk istorii (1917-1990) [Soviet peasantry. A short history essay (1917-1990)]. Moscow, Izdatel'stvo politicheskoi literatury, $214 \mathrm{p}$. 
Deviatoe ianvaria [Ninth of January]. (1925). Ed. A.A. Shilov. Moscow, Gosudarstvennoe izdatel'stvo, $311 \mathrm{p}$.

Efimenko, A. (1884). Research of national life. Moscow, V.I. Kasperov, 301 p.

Firsov, N.N. (1920). Razinshchina kak sotsial'noe i psokhologicheskoe iavlenie narodnoi zhizni [Razin revolt as a social and psychological phenomenon of people's life]. Moscow, Gosudastvennoe izdatel'stvo, 71.

Golubykh, N. (1926). Ocherkiglukhoi derevni [Essays of a deaf village]. Moscow, Gosudarstvennoe izdatel'stvo, $154 \mathrm{p}$.

Iushkov, S.V. (1913). Ocherki po istorii prikhodskoi zhizni na Severe Rossii. XV-XVII vv. [Essays on the history of parish life in the North of Russia. $15-17^{\text {th }}$ centuries]. Saint Petersburg, tipografiia M.A. Alexandrova, $157 \mathrm{p}$.

Ivanov, M.I. (1905). Sel'skoe dukhovenstvo v Tverskoi gubernii XVIII i nachala XIX stoletiia v otnoshenii k krepostnomu pravu [Rural clergy in the Tver governorate of the $18^{\text {th }}$ and beginning of the $19^{\text {th }}$ centuries in relation to serfdom]. Tver, tipo-litografiia M.V. Blinova, $317 \mathrm{p}$.

Kaufman, A. (1905). Pereselenie i kolonizatsiia [Resettlement and colonization]. Saint-Petersburg, tipografiia tovarishchestva "Obshchestvennaia pol'za", 478 p.

Kizevetter. (1923). Krest'ianstvo v Rossii [Peasantry in Russia]. (2-3). Prague: Publishing House "Krest'ianskaia Rossiia”, 418 p.

Kolesnikov, B. (1925). Derevnia. Kuda ona idet? [A village. Where is it going?], Kharkov, Proletarii, $83 \mathrm{p}$.

Krest'ianskoe dvizhenie v revoliutsii 1905 goda. V dokumentakh [Peasant movement in the revolution of 1905. In documents] (1926). Ed. N. Karpova, Gosudarstvennoe izdatel'stvo, 310 p.

Kretov, F. (1925). Krest'ianstvo v revoliutsii 1905 goda [Peasantry in the revolution of 1905]. Moscow-Leningrad: Moskovskii rabochii, 325 p.

Leningradskie rabochie v derevne. Itogi letnikh rabochikh otpuskov v 1929 [Leningrad workers in a village. Results of summer vacations in 1929] (1925). Ed. N. Matorikh. Leningrad, Priboi, 177 p.

Litvak, B.G. (1989). Krest'ianskoe dvizhenie v Rossii v 1773-1904 godakh [The Peasant Movement in Russia in 1773-1904]. Moscow, Nauka, 256 p.

Ostrovskaya, M. (1912). Drevnerusskii severnyi mir [The Old Russian Northern World]. Arkhangelsk, gubernskaia tipografiia, 89 p.

Pokrovskii, F.D. (1989). Iz dnvenika. Dokumenty svidetel'stvuiut [From the diary. Documents evidence]. Ed. V.P. Danilov and N.P. Nivnitskii. Moscow, Izdatel'stvo politicheskoi literatury, 362-412.

Rakhmatullin, M.A. (1990). Krest'ianskoe dvizhenie v Velikorosskikh guberniiakh v 1826-1857 gg. [The peasant movement in the Great Russian regions in 1826-1857]. Moscow, Nauka, $300 \mathrm{p}$.

Sokolov, P.P. (1895). O znachenii prikhodov do XVIII v. [On the significance of the parishes until the $18^{\text {th }}$ century], Yaroslavl, gubernskaia tipografiia, $137 \mathrm{p}$.

Solonevich, I.L. (1991). Narodnaia monarkhiia [The People's Monarchy], Moscow, Phoenix, 624 p.

Spiridovich, A.I. (1918). Partiia sotsialistov-revoliutsionerov [The Party of SocialistRevolutionaries]. Prague, voennaia tipografiia, $247 \mathrm{p}$.

Stopanin, A.M. (1926). Ocherki novoi derevni i partraboty v nei. Po materialam Volokamskogo uezda [Essays on a new village and party work in it. Based on the materials of Volokamsky Uyezd]. Moscow, Moskovskii rabochii, $72 \mathrm{p}$. 
Tikhomirov, L. (1998). Monarkhicheskoe gosudarstvo [The Monarchical State]. Moscow, State Unitary Enterprise “Oblizdat”, "Alir” LLP, 672 p.

Ulasevich, L. (1930). Preniia po dokladu. Osnovnye voprosy kollektivizatsii [Debate on the report. Basic issues of collectivization]. Discussion in the Communist Academy. Moscow, izdanie Komakademii, 17-23.

Znamenskii, P. (1873). Prikhodskoe dukhovenstvo v Rossii vo vremia reform Petra [Parish clergy in Russia during Peter's reforms]. Kazan, universitetskaia tipografia, 587 p.

\title{
От крестьянского «мира» к колхозу: \\ как созревали предпосылки революционной катастрофы \\ в русской деревне
}

\author{
С.В. Лурье \\ Социологический институт ФНИСЦ РАН \\ Россия, 198005, Санкт-Петербург, \\ ул. 7-я Красноармейская, 25/14
}

\begin{abstract}
Русская крестьянская картина мира строилась на взаимодействии и противодействии двух внутренних альтернатив: «мирской» (общинной) и государственной. Общчина, возникнув на Руси в XIII-XIV вв., заняла ијентральное место во всех сферах жизни крестьянина, став и самоуправляюшимся автономным «миром», и экономическим институтом, и религиозным единством - иерковным приходом. Да и само государство воспринималось крестьянами как большая община. В эпоху крепостничества община, юридически лишенная всякой защиты, в понимании крестьян становится единственным источником легитимности. Она, опираясь на присутствующий в сознании крестьян образ должного государства, борется за самоуправление и «черный передел» как справедливое землеустройство, и крестьянские бунты в России не затихают.

Помимо малоземелья, частично смягчаемого только колонистским движением в восточные регионы Российской империи, продолжающимся напряжением между «миром» и государством, причиной револючионизачии крестьянской общины кXX в. стало определенное искажение ее приходского начала с заметным ослаблением религиозности крестьян, без которой «мирская» альтернатива превращалась в самоцель. И на крестьян рубежа ХІХ и ХХ вв. сильнее подействовала пропаганда провокаторов-революиионеров, призывавщих к насильственному «черному переделу».

После 1917 г., приняв «черный передел» от безбожного советского государства, община утратила свой идеальный смысл, а баланс между мирской и государственной альтернативами в крестьянской картине мира был нарушен. В результате община, приняв в 1920-е г2. советское государство как свое, а государственный атеизм как «государственную религию», оказывается неготовой противостоять коллективизачии. Впервые за века крестьяне не ожидают от государства враждебных действий, и именно тогда получают от него удар в спину.
\end{abstract}

Ключевые слова: русская крестьянская община, иерковный приход, крестьянский бунт, коллективизация.

Научная специальность: 24.00.00 - культурология. 
